\title{
Exploration of the Construction Model of School-Business Collaboration System in Vocational Colleges Based on Information Resource Sharing
}

\author{
Fang $\mathrm{Wu}^{1}$ and Ying $J i \mathbb{C}^{1,2}$ \\ ${ }^{1}$ Wuxi Vocational College of Science and Technology, No. 8 Xinxi Road, Wuxi, Jiangsu 214000, China \\ ${ }^{2}$ Ajou University, Suwon 16499, Republic of Korea \\ Correspondence should be addressed to Ying Ji; jy@wxsc.edu.cn
}

Received 7 December 2021; Revised 25 December 2021; Accepted 27 December 2021; Published 28 February 2022

Academic Editor: Tongguang Ni

Copyright (c) 2022 Fang Wu and Ying Ji. This is an open access article distributed under the Creative Commons Attribution License, which permits unrestricted use, distribution, and reproduction in any medium, provided the original work is properly cited.

\begin{abstract}
The exchange of literature and information resources between higher vocational colleges and cooperative enterprises is a win-win situation in which both parties benefit. Collaboration between schools and businesses is a significant departure from the traditional vocational education model, as well as an innovation in the talent training model, an important direction of higher vocational education reform, and the focal point for the formation of vocational education characteristics. Collaboration between schools and businesses is now not only an effective way for businesses to train a large number of applied technical talents, but also an effective way for vocational colleges to change their disciplinary structure. At the same time, collaboration between schools and businesses is critical to the advancement of vocational education. The focus of this article is on the publication of literature on the long-term mechanism of school-business collaboration, the field of research on the long-term mechanism of school-business collaboration, state laws and regulations on school-business collaboration, and academic opinions. The content, mode, problems to be solved, and importance of sharing document information resources in school-business collaboration are the main topics of this article. Vocational technical colleges and businesses should benefit from each other and maximize their respective advantages in school-business collaboration. One of the greatest advantages of higher vocational colleges is the abundance of literature and information resources. This article will raise a key question through a review of the literature: how can you establish an effective long-term mechanism for school-business collaboration? This theory has been enhanced by previous research in order to put the issue of school-business collaboration into practice and provide theoretical and practical guidance that will benefit the country, society, schools, and, most importantly, student employment.
\end{abstract}

\section{Introduction}

Vocational education cannot become vocational education in the true sense without the participation of enterprises. Only the close cooperation between schools and enterprises can fundamentally realize the authenticity of the training teaching environment, facilities and methods, the duality of students' roles, and the training of teachers, the dual-teacher nature, the mutual benefit of education funding (enterprise training funding-government investment funding), the security of systems and information, and so on. How to realize the sharing and optimal allocation of educational resources and achieve the goal of mutual assistance, mutual benefit, and win-win in school-business collaboration is a topic of common concern and discussion among all sectors of society [1]. School-business collaboration is an innovative model for schools and enterprises to cultivate and accept talents. In a practical sense, on the one hand, it can solve the employment problem of students and reduce employment pressure; on the other hand, this method can solve the problem of shortage of talents in enterprises. It can be seen that a successful school-business collaboration will undoubtedly become a win-win model for the development of schools, enterprises, individual students, and society. 
The way of school-business collaboration is conducive to the adjustment of local economy, is conducive to the transformation of scientific and technological achievements into actual productivity, and is more conducive to driving the adjustment of local economy, thereby promoting the prosperity and development of local economy. Relatively speaking, in the process of school-business collaboration in running schools, the enterprise is the main body of the cooperation, and the enterprise pays more [2]. Accepting students for internships will add additional burden to the factory, also taking responsibility [3]. Higher vocational colleges are relatively in the secondary side and need to find companies everywhere to cooperate, seeking companies to receive student training and internships [4].

To some extent, the provision mode of information resource sharing can bridge this gap. Because higher vocational colleges are the primary parties and instructors in the sharing of literature and information resources, they can proactively provide literature and information services to businesses, assist businesses in developing joint information resources, and benefit businesses. More literature information resources are required for the development of related cooperative enterprises or the ability to accept more students [5]. For mutual benefit and mutual benefit, both schools and businesses can make full use of literature and information resources. Enterprises can save a portion of their manpower, material resources, and financial resources by reducing unnecessary document duplication. Both sides can benefit from each other, complement each other, and grow together, bringing the two parties' cooperation relationship closer together. Simultaneously, through information resource sharing and cooperation, all types of enterprise information can be fed back to higher vocational colleges in a timely manner, facilitating the adjustment of professional directions or enrollment plans, the organization of training projects, and the implementation of employment indicators for higher vocational colleges. Colleges and universities use an order-style approach to talent development [6].

In the school-business collaboration, the key point is how to establish a sharing mechanism between the school and the enterprise, so that both parties can make full use of the literature and information resources, communicate with each other, maintain a close relationship, and obtain what they need to achieve a win-win goal. System guarantee for the sharing of literature information resources in schoolbusiness collaboration [7] includes centering on the library of the higher vocational college, providing rules and regulations for the use of literature and information resources, rules and regulations for the use of school-enterprise network resources, funding and sharing system for information resource development and sharing, and the internal construction and development of libraries in higher vocational colleges., where the library should do a good job in the integration of document information resources and highlight key majors in accordance with the professional settings of the hospital. According to the needs of cooperative enterprises, production and R\&D projects expand the collection of relevant professional and project literature and information, highlighting local characteristics [8].

\section{Related Work}

School-business collaboration plays an important role in improving the technological competitiveness of enterprises and expanding their technological resources. School-business collaboration has also accelerated the process of marketization of new technologies. Universities and enterprises at home and abroad are constantly conducting research and practice to explore better school-business collaboration models. Therefore, a key issue in the study of school-business collaboration is how to scientifically and effectively evaluate school-business collaboration projects.

According to [9], higher vocational colleges' financial investment is insufficient, and the conditions for running schools, particularly experimental training conditions, are relatively weak: The school-business collaboration mechanism is not perfect; the cooperation has not yet established a fixed base for industry-university-research cooperation; theoretical research on school-business collaboration in higher vocational education lags behind. According to [10], vocational education still has issues such as a lack of social recognition, a backward professional setting, and an unreasonable curriculum setting; key points and teaching difficulties are not prominent; and practical links are severely lacking. School-business collaboration, according to [11], is beneficial to resolving the supply and demand of talents between schools and businesses; it is beneficial to accurately positioning the goals of higher vocational education; it is beneficial to broadening the employment channels for students in higher vocational colleges; and it is beneficial to the formation of higher vocational colleges, the characteristics of a school principal. The difference is that [12] also suggested that collaborating between schools and businesses can significantly improve the conditions for running schools in higher vocational colleges. According to [13], schoolbusiness collaboration is also conducive to educational reform and talent training model reform; it is conducive to enterprise participation in the school talent training plan and process, as well as deepening the teaching reform; it is conducive to enterprises mobilizing their enthusiasm and initiative to run schools. In the course of running a school, we will make full use of the enterprise's human and material resources. Literature [14] based on the analysis of schoolbusiness collaboration model, guaranteed mechanism, monitoring, and evaluation mechanism and gave a set of evaluation index system for the quality of school-business collaboration. This achievement has important reference significance in enriching the theoretical system structure of higher education evaluation, improving the school-enterprise cooperative education and teaching quality evaluation system, and improving and ensuring the quality of education and teaching in schools. Literature [15] studied the research and practice of the school-business collaboration talent training model in higher vocational colleges. The development, change, and evaluation of the relationship between colleges and enterprises have gradually become the focus of researchers and the main concerns of practitioners. On the basis of the research of resource dependence theory, the effectiveness of cooperation between the two parties and the 
degree of resource dependence and difficulty establish a stable degree of influence. The relationship between the dependence structure of teaching management, analysis, and discussion shows that the impact of school-business collaboration is not only the relationship with teaching management, the degree of dependence on resources of the two parties' symbiosis, and the relationship with cooperation; the influencing factors are far greater than the degree of dependence on resources. Literature [16] aimed at the goal of talent training in higher vocational colleges, constructed a basic school-business collaboration teaching quality evaluation system with diversified subjects such as schools and enterprises (industry, employers), and demonstrated the diversified subjects and diversified subjects of teaching quality evaluation, with the choice of the evaluation method and the determination of diversified evaluation items. Literature [17] pointed out that the development of modern higher vocational education will inevitably promote cooperative education between schools and enterprises. Constructing a scientific and objective evaluation system for school-business collaboration will provide strong support and reference for the smooth development of school-business collaboration. Wang Ning put forward his own ideas on the construction of the evaluation system of school-business collaboration in higher vocational education.

For most companies, they do not evaluate success based on the financial benefits of cooperative research and development management or the number of research results. In order of importance, success is achieved by cooperation between companies that achieve the following goals: increase the understanding of new technologies and new technologies; provide employees with opportunities to acquire new knowledge; improve strategic thinking; obtain well-trained employees and knowledge of more access to property rights, improved corporate credibility, and better employee recruitment.

Literature [18] overviews the research in recent years; often it is the school's keen interest in school-business collaboration and the combination of work and learning that make the school-business collaboration a bottleneck. The primary issue is that collaboration begins only from the perspective of the school, ignoring the feelings of the enterprise, emphasizing the enterprise's public welfare and social duty, and ignoring the enterprise's needs. To break through this bottleneck, it is necessary to think about the composition of the performance evaluation index of the combination of work and study based on the perspective of corporate interests. Higher vocational education cultivates talents that directly benefit business and industry, while cooperative colleges and universities cultivate talents that directly or indirectly benefit business, allowing schoolbusiness collaboration to grow in depth and breadth and be long-lasting and smooth. China's higher vocational education has achieved "school-business collaboration, workstudy integration," according to [19]. Although some progress has been made, a long-term operating mechanism and a complete system have yet to be established. In the implementation process, there are still some issues to be resolved in the use of the School-Business Collaboration
Talent Training Model. It is difficult to overcome the traditional closed teaching quality monitoring system. We must improve teaching quality evaluation to adapt to the open system of higher vocational education talent training model of "school-business collaboration, work-study integration." There are also studies that use specific data as a basis for evaluating school-business collaboration through the creation of data models. For example, [20] shows that the overall level of cooperation between financial vocational schools and enterprises is relatively low, based on principal component analysis and empirical analysis of seven types of finance and economics on the performance of higher vocational school-business collaboration. There is a significant disparity between the two, as well as an imbalance; the success of school-business collaboration is dependent on the cooperation, process, and impact of school and enterprise resources. The two decisive factors are that we must place a high value on enterprise participation. As soon as possible, a multichannel and multidirectional exploration of schoolbusiness collaboration methods strengthen interschool cooperation and strengthen the radiation model and the leading role of key universities should be included in relevant local laws and regulations.

For the evaluation of the effect of school-business collaboration, two aspects are involved in the specific implementation process, namely, the establishment of the effect evaluation index system and the implementation of the effect evaluation. This article will discuss and determine the index system for evaluating the effectiveness of school-business collaboration projects through methods such as literature review, research, interviews, and specific school-business collaboration projects. Then the use of the evaluation index system should cover the effects of school-business collaboration projects in the tripartite of enterprises, universities, and the government.

\section{Document Information Resource Sharing in School-Business Collaboration Forms Complementary Advantages}

In the school-business collaboration, the advantage of the enterprise lies in the fact that the enterprise can provide students in higher vocational colleges with internship places, training, and employment opportunities. Enterprises have advantages in equipment resources. It can be used by students for practical operation. The enterprise has advantages in production technology and industry, and its personnel can guide students on-site, so that students can master certain skills. The company also provides job opportunities, so that some of the students can stay in for employment. The disadvantage is that companies mainly consider problems from economic benefits or are affected by economic operating cycles and are unwilling to invest funds in the construction of literature and information resources. Some enterprises are biased towards short-term behaviors, lack long-term benchmarks, and do not pay attention to the construction of literature and information resources at all. Enterprises lack professional management personnel of 
document information, which also affects the construction of document information resources [21].

Rich books and literature information resources, a certain amount of storage, and the formation of a librarycentered literature information resource database are all advantages of higher vocational colleges. Have professional personnel who are involved in the collection and use of literature information and materials, as well as specific work experience. Take advantage of technical theoretical advantages in computer and network technology applications. Relevant professional teachers and skilled teachers are available. They have a certain theoretical and practical level of knowledge, a better understanding of the state of development of a particular industry and profession, and guiding advantages in certain professions and industries. The disadvantage of higher vocational colleges stems from the fact that college operation management differs from enterprise operation management. It is easy to cause information uncertainty because it does not fully comprehend the actual situation of enterprise literature information needs. Higher vocational colleges have strict school funding management and limited funds, making larger projects difficult. Figure 1 depicts the talent development model.

In Figure 1, higher vocational colleges and enterprises share resources such as talents, technology, information, and funds. The government supervises and coordinates their cooperation and constantly makes adjustments based on their feedback information to ensure smooth cooperation.

Higher vocational education necessitates a close relationship between schools and businesses. Vocational schools collaborate with businesses and serve them in order to gain their support, assistance, and participation in order to expand their development space. In our country, there is currently a significant disconnect between higher vocational education and the business community. Enterprises are not overly enthusiastic about participating in higher vocational education. Disconnection between theoretical and practical teaching is a common problem in higher vocational colleges. The government must be involved in solving these issues. To realize the sharing of educational resources, Taiwan should follow the path of school-business collaboration and schoolschool cooperation in running schools and establish vocational education groups based on the principles of equality, voluntariness, mutual benefit, and common development. Form a school-business collaboration group school structure in which the school provides teaching management sites and basic theory teachers, while the enterprises provide equipment, technology, internship training bases, part-time teachers, and job opportunities.

\section{Platform Design and Implementation}

The school-business collaboration professional teaching system of information resource sharing highlights the benign interaction of the school-business collaboration behavior. It is a concise and quite operable theoretical framework of teaching structure. Compared with other teaching modes, it also consists of four elements: theoretical basis, functional goals, realization conditions, and activity procedures.

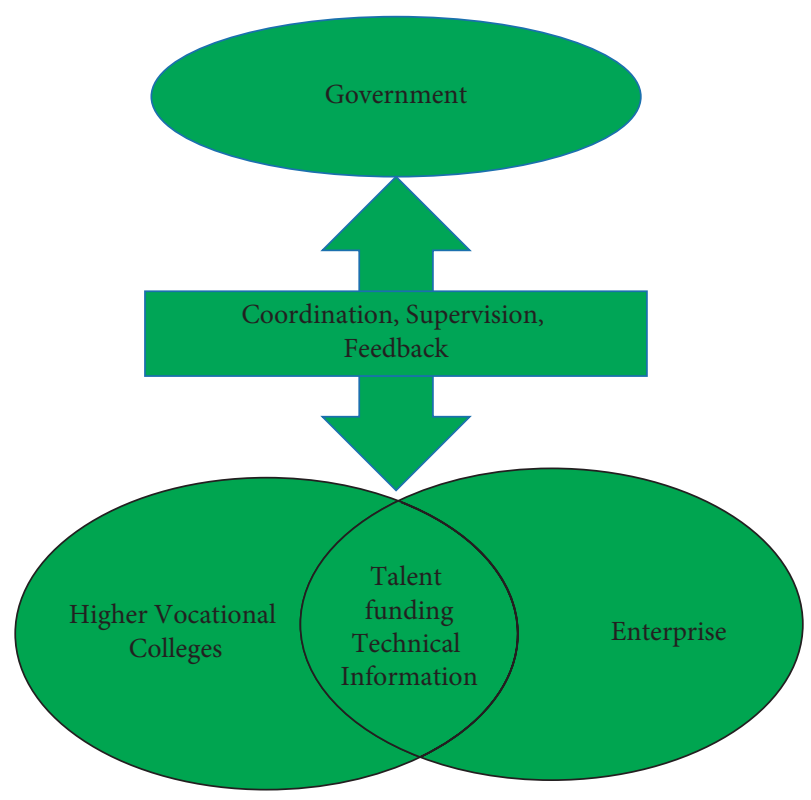

Figure 1: Talent training model.

Cultivate vocational technical personnel and high-quality laborers with dialectical materialist worldview, outlook on life and good professional ethics, and being capable of serving the front line of production. It is necessary to attach importance to the mastery of basic cultural and professional knowledge of students, but also to emphasize the cultivation of professional practical skills. At the same time, in accordance with the industrial characteristics of the cluster economy and the skill requirements of the industrial post group, vocational and technical personnel with intermediate and primary operating skills are trained. Make full use of the human, information, and material resources provided by modern enterprises and combine the characteristics of vocational education to conduct professional teaching. At the same time, it is necessary to achieve the necessary conditions for the benign interaction between the school and the enterprise in cooperation concepts, teaching training, and technology research and development. The details are shown in Figure 2.

The traditional teaching mode is frequently limited to the school's professional theory teaching in the activity procedure and rarely includes the teaching of corporate job group professional skills. The professional teaching model of information resource sharing for school-business collaboration includes not only the theoretical teaching of professional courses in the school, but also the teaching of professional skills and enterprise job skills training [22]. At the same time, the two parties' friendly interaction is the behavior that runs throughout the entire program. As one of the primary pillars of school-business collaboration, the school should fully implement the college's guidance on students' ideological behavior and the development of a sound personality and continuously improve its own schoolrunning level with the help of industry and enterprise resources. Enterprises should actively participate in the process of educating people, extensively participating in all stages of student training, sharing resources, complementing 


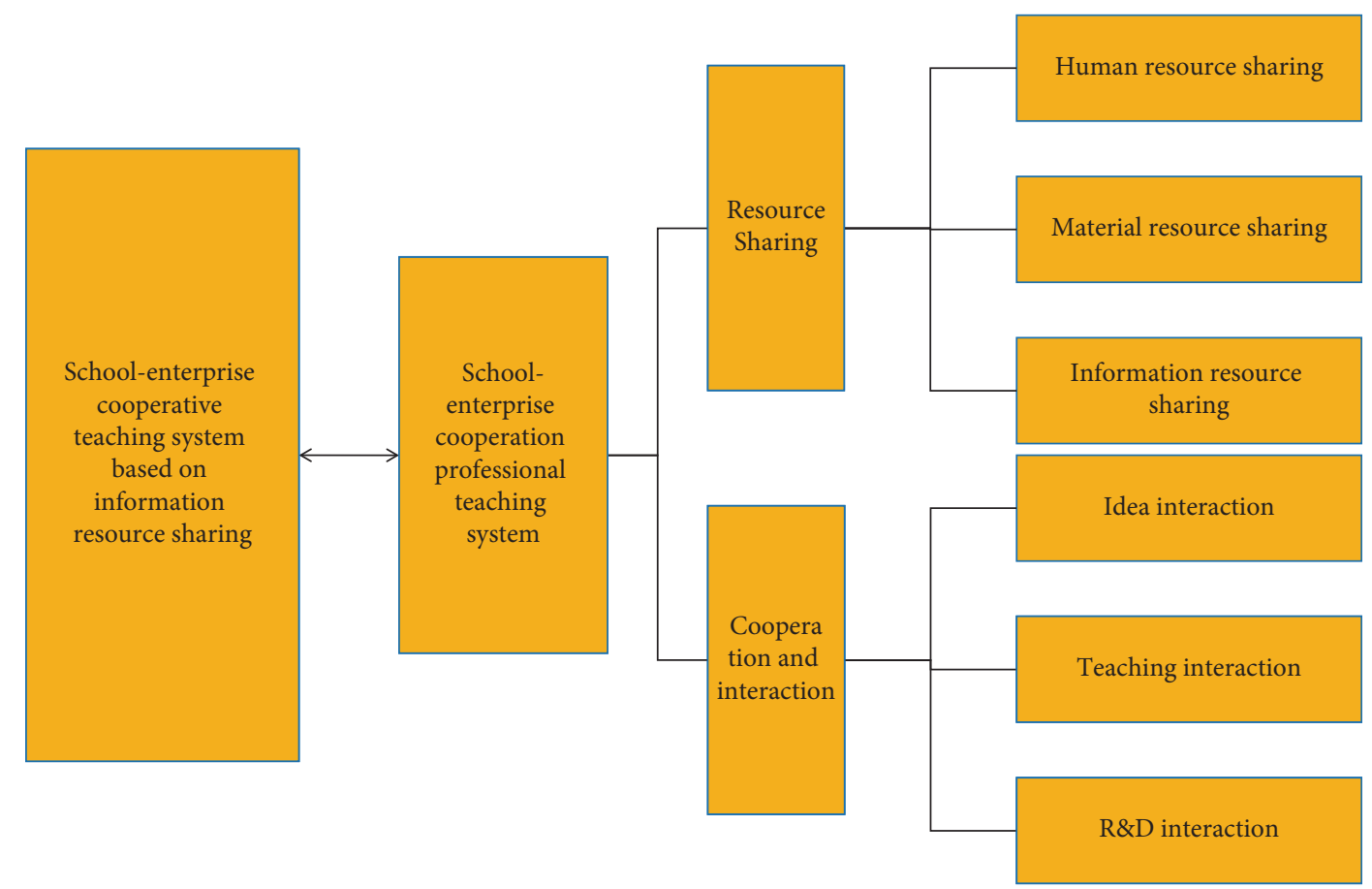

FIGURE 2: The basic framework of a school-business collaboration professional teaching system based on information resource sharing.

each other's advantages, educating people through science and technology, and technological innovation, achieving corporate profitability and social responsibility, as well as self-development and development, as another important subject of educating people. Industrial development has a high degree of coherence.

\section{Research on the Importance of Factors Influencing Enterprise Innovation and Entrepreneurship Based on Information Resource Sharing}

5.1. School Evaluation Index Selection. Higher vocational colleges can use the tangible assets of enterprises to provide students with internship places. The training goal of higher vocational education is that talents must have strong technical application ability and strong professional quality. This requires higher vocational education to pay special attention to practical teaching links. There are some experiences and contingency methods that cannot be taught in the classroom. It is possible to be sure of repeated training in a real live environment. Under the current situation where education investment is generally insufficient, it is difficult for schools to provide on-site environments, i.e., internships and training bases, and there is no need to set up a factory for each major as a training place for students. With the support of enterprises, vocational colleges can obtain experimental equipment funding or establish professional practice bases, improve teaching facilities or provide good conditions for practical training, and provide hardware guarantees for cultivating talents.
In order to understand the binary subclassification problem between class $j$ and class $k$ and maximize the boundary between the information resource sharing data, the soft-margin objective function is shown in (1) and (2).

$$
\begin{gathered}
\min w_{j} w_{k}=\left\|w_{j}-w_{k}\right\| \frac{1}{2}+c \sum_{y_{i} \in\{j, k\}} \xi_{i}^{j k}, \\
y_{i}^{j k} f_{j k}\left(x_{i}\right) \geq 1-\xi_{i}^{j k} .
\end{gathered}
$$

Among them, $x i \in R d$; $\xi_{i}^{j k}$ is nonnegative slack variables used to deal with nonlinear data classification problems; assuming that there are a total of $c$ attributes, then there are a total of $c(c-1) / 2$ binary subclassification problems. An information resource sharing model is shown in formulas (3) and (4):

$$
\begin{gathered}
\min w_{j} w_{k}=\frac{1}{2} \sum_{j=1}^{c-1} \sum_{k=j+1}^{c}\left\|w_{j}-w_{k}\right\|_{2}^{2}+c \sum_{j=1}^{c-1} \sum_{k=j+1}^{c} \sum_{y_{i} \in|j, k|} \xi_{i}^{j k}, \\
y_{i}^{j k} f_{j k}\left(x_{i}\right) \geq 1-\xi_{i}^{j k} .
\end{gathered}
$$

When using model (2) to classify the samples, a voting mechanism is used; More categories Ij satisfy the relation. Finally, the predicted category of the sample will get the highest number of votes, as shown in formula (5).

$$
\tilde{y}_{i}=\arg \max _{j} w_{j}^{T} x_{i}+b_{i}
$$


TABLE 1: Analysis results of factors affecting information resource sharing school-business collaboration.

\begin{tabular}{lccc}
\hline & Dependency & Predictive correlation & Maximum sample dependence probability \\
\hline Government policy support (GPS) & Higher & Higher & 0.732 \\
School entrepreneurship support (SES) & Higher & High & 0.876 \\
School's innovation support (SIS) & Higher & Higher & 0.762 \\
Enterprise's support for entrepreneurship (ESE) & High & Very high & 0.951 \\
Education (EDU) & Higher & Higher & 0.769 \\
Participation in the internship (PTI) & Middle & Lower & 0.603 \\
Individual ability (IAB) & High & High & 0.944 \\
Awareness of entrepreneurial risk (AER) & Higher & High & 0.892 \\
Entrepreneurial motivation (EMO) & Higher & Higher & 0.824 \\
Entrepreneurial determination (EDE) & Higher & Higher & 0.798 \\
\hline
\end{tabular}

In order to verify the effectiveness of the proposed model, the entrepreneurial data in $[23,24]$ is used as the data sample. The influencing factors considered for information resource sharing are shown in the first column of Table 1. There are five categories of influencing factors: low, low, medium, high, and high. The information resource sharing of model (2) is applied to the sample data, and the specific results are shown in Table 1.

The success of students' innovation and entrepreneurship depends heavily on the support of schools and enterprises to innovation and entrepreneurship. The experimental results in Figure 3 show that the model of school-business collaboration based on information resource sharing is conducive to promoting college students' innovation and entrepreneurship.

5.2. Selection of Enterprise Evaluation Index. The success of school-business collaboration projects for businesses is measured not only in terms of financial gains, but also in terms of scientific research and development progress. The ability to maintain a leading position in technology; the ability to increase training opportunities for corporate employees; the richness of human resource reserves; the improvement of the corporate reputation, and so on are all factors that influence the success of school-business collaboration for businesses. Students who stay in the company as part of the school-business collaboration project can save the company money on recruitment, training, and other costs by providing qualified employees who meet the company's needs directly. In summary, the following evaluation indicators were chosen for the school-business collaboration project: Corporate: corporate reputation, financial income, employee training, and student acceptance or recommendation for employment: work ability, professional characteristics, and competitiveness.

Construct a judgment matrix. For the indicators to be investigated in the target layer and the criterion layer, the average scores of the experts on the indicators are calculated to construct a matrix table. There are two calculation methods: geometric average method and standardized column average method. Calculate the consistency check coefficient C.R. and make a judgment:

$$
\text { C.R. }=\frac{\text { C.I. }}{\text { R.I. }}
$$

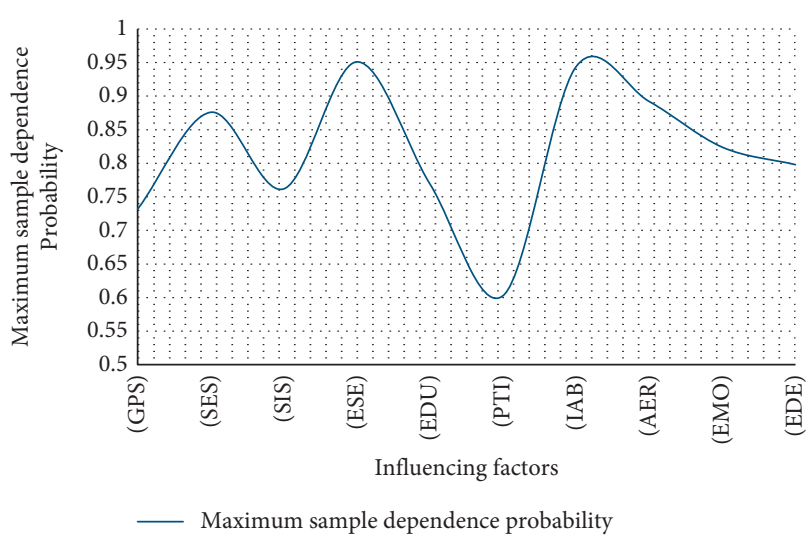

FIGURE 3: Analysis results of factors affecting information resource sharing school-business collaboration.

When C.R. $<0.1$, it is considered that the consistency of the judgment matrix is acceptable; when C.R.> 0.1, it is considered that the judgment matrix does not meet the consistency requirements, and the judgment matrix needs to be revised. The average random consistency index of the matrix is shown in Figure 4.

Calculate the weights between the criteria under the target layer. First, average the scores of the experts and the structure is shown in Table 2 and Figure 5.

Consistency check C.I. $=(\lambda \max -n / n-1)=(5.195-5 / 5-1)=0.5$. So the judgment matrix passed the one-time test.

5.3. Single-Level Evaluation of the Effects of School-Business Collaboration Projects. The overall effect of school-business collaboration projects is evaluated in this article using a fuzzy analytic hierarchy process. This evaluation method, which combines the two methods, can not only compare the important lines of the evaluation indicators of the schoolbusiness collaboration project, but also quantitatively reflect the overall effect of the school-business collaboration project, which improves the project's effect. Aspects can provide a more focused foundation. A judging group is chosen from among the project participants or benefiting personnel from schools, businesses, and governments in this paper. Based on the connotation of each evaluation index, 


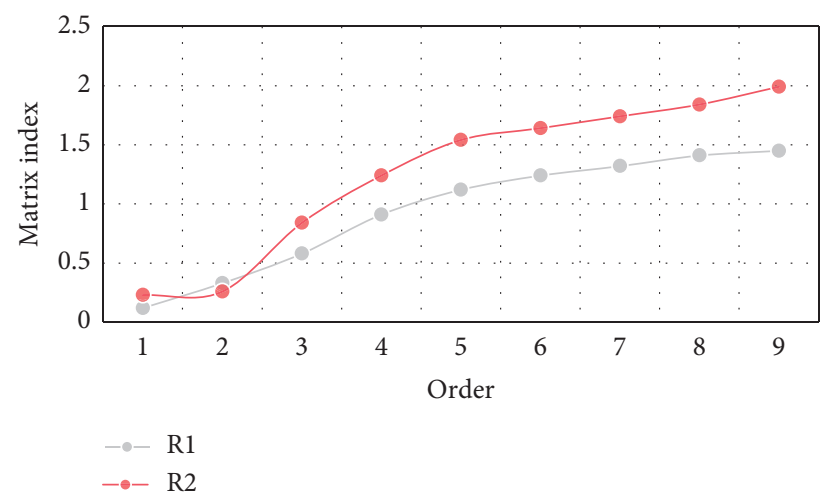

Figure 4: The average random consistency index of the matrix.

TABle 2: The structure of the judgment matrix.

\begin{tabular}{lccccc}
\hline Level a & $\mathrm{A} 1$ & $\mathrm{~A} 2$ & $\mathrm{~A} 3$ & $\mathrm{~A} 4$ & $\mathrm{~A} 5$ \\
\hline B1 & 1 & 0.25 & 0.261 & 0.778 & 4.333 \\
B2 & 4 & 1 & 1.833 & 5.667 & 7.333 \\
B3 & 3.383 & 0.545 & 1 & 4 & 6 \\
B4 & 1.286 & 0.176 & 0.25 & 1 & 3.667 \\
B5 & 0.231 & 0.136 & 0.167 & 0.273 & 1 \\
\hline
\end{tabular}

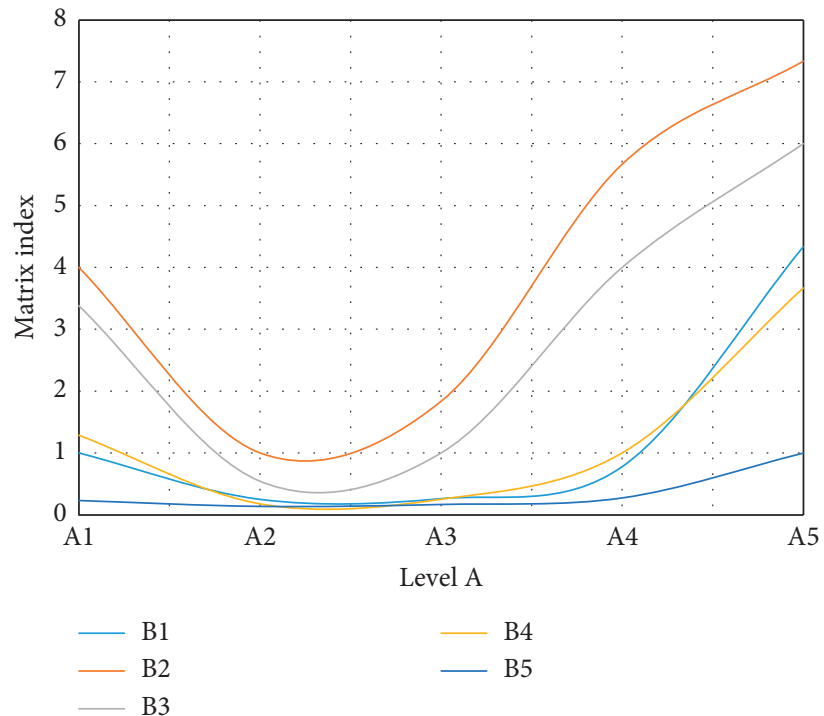

Figure 5: The structure of the judgment matrix.

the judging group will vote on a set of comments. Table 3 and Figure 6 are the statistical process for voting results.

After weighting the weights of each indicator at the scheme layer and the weight of each indicator at the criterion layer, the total ranking weight of each indicator at the scheme layer is obtained. The total ranking of the indicators at the scheme layer is as follows:

From Figure 7, Figure 8, Figure 9, Figure 10, and Figure 11, the fuzzy matrix between the school-business collaboration project effect $\mathrm{A}$ and the comment set $v$ can be obtained from the single-level evaluation result of the school-business collaboration project effect. The effect of enterprise-enterprise cooperation projects is good, $22.5 \%$ of people think that the effect of school-business collaboration projects is average, and $9.4 \%$ of people think that the effect of school-business collaboration projects is very poor. During the operation of the project, the focus of both parties is mostly on strengthening the training of students through various means, in order to enhance students' professional ability and employment competitiveness. For the project itself, it is easier for this approach to obtain a more obvious effect. However, from the perspective of the development of the school, only through the school-business collaboration project to promote the improvement of the teacher's level 
TABLe 3: Relationship between criterion level and program level.

Teacher improvement B1

Student employment B3
Teacher training C11

Academic research promotion $\mathrm{C} 12$

Training cost C21

Curriculum effectiveness C22

Professional recognition C23

Core competence value-added C24

Graduation design quality C25

Career planning awareness C31

Employment rate $\mathrm{C} 32$

Professional relevance $\mathrm{C} 33$

Occupational brother at coincidence degree C34

Value-added professionalism C35

Corporate reputation $\mathrm{C} 41$

Financial income C42

Staff training C43

Working ability C44

Professional characteristics and competitiveness C45

Employment area C51

Income level C52

Government B5

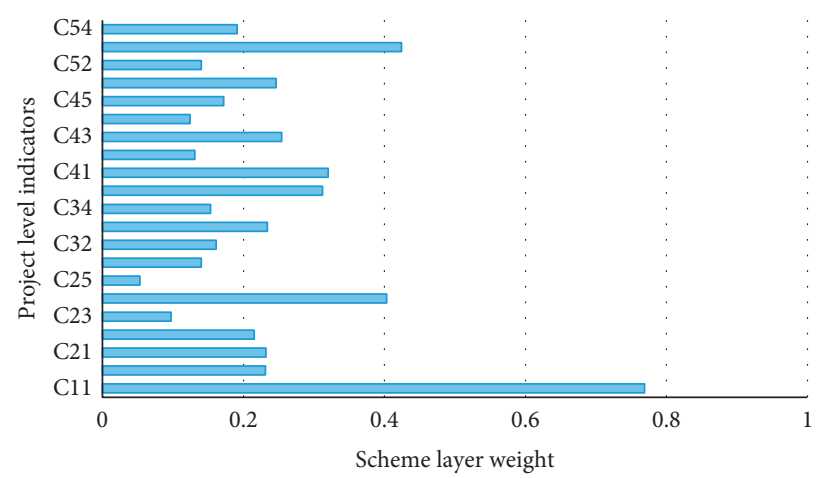

Figure 6: The weight index of the scheme layer.

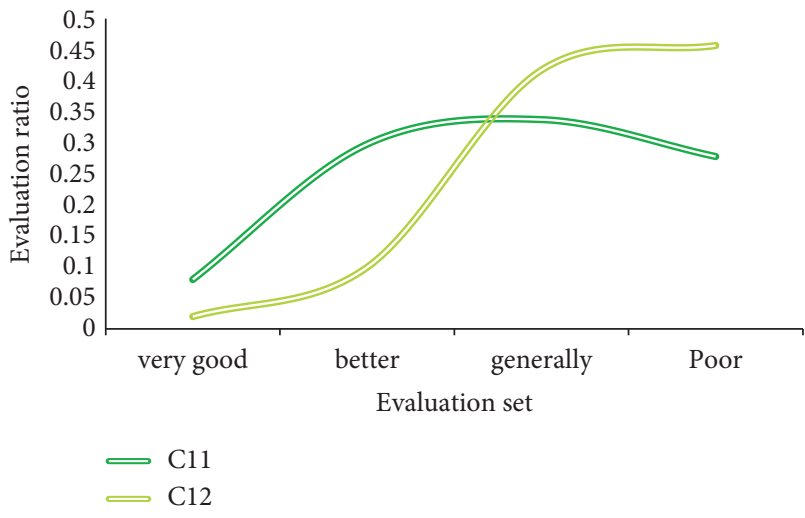

Figure 7: The ratio of teachers to improve B1 evaluation.

can the theoretical knowledge mastered by the teacher be better combined with the actual production, and the teacher with the "double-qualified" quality can be cultivated. The improvement of quality has cultivated more students with

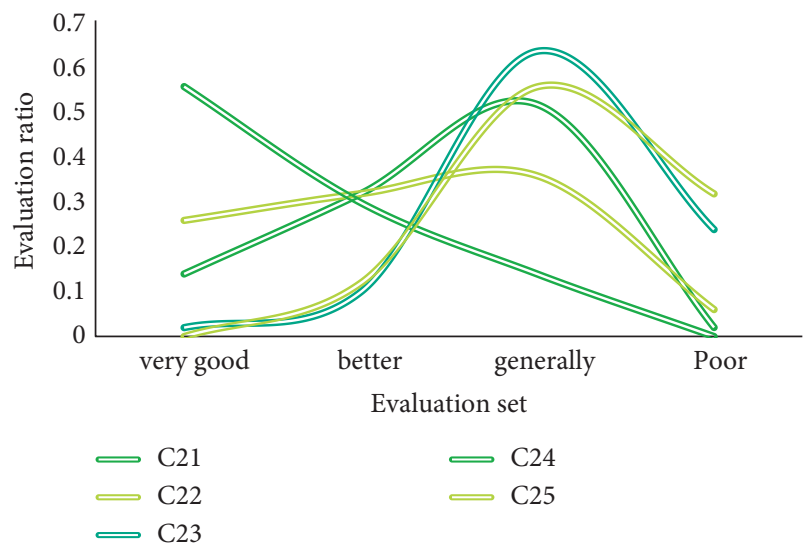

Figure 8: B2 evaluation ratio of student training.

practical ability for schools and society and cultivated more employees with excellent professionalism for enterprises to promote the reform of teaching. 


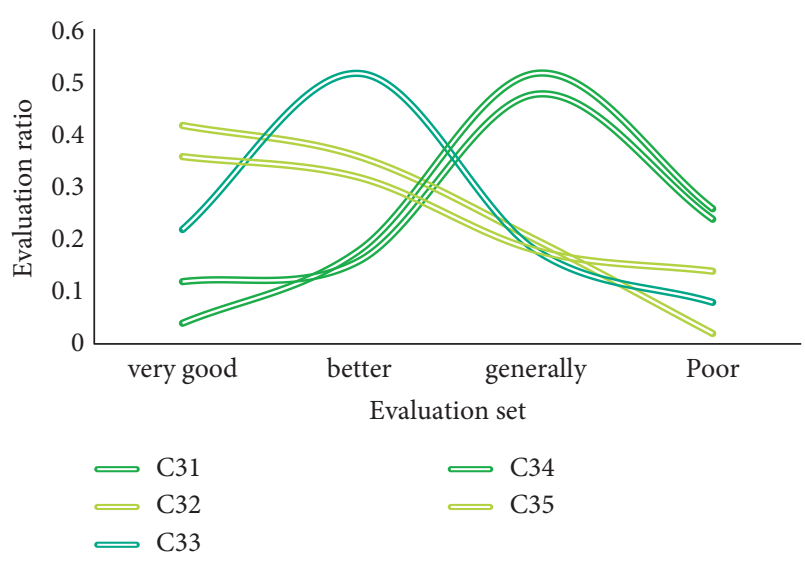

Figure 9: B3 evaluation ratio of student employment.

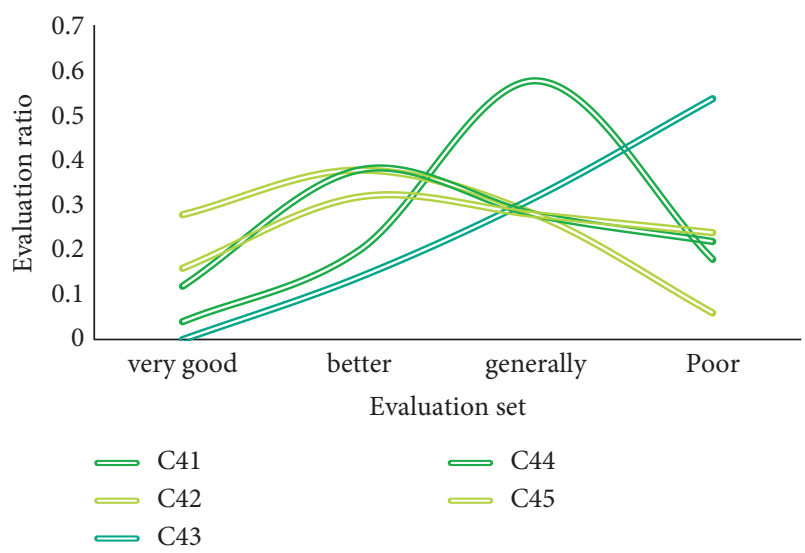

FIgURE 10: Evaluation ratio of enterprise B4.

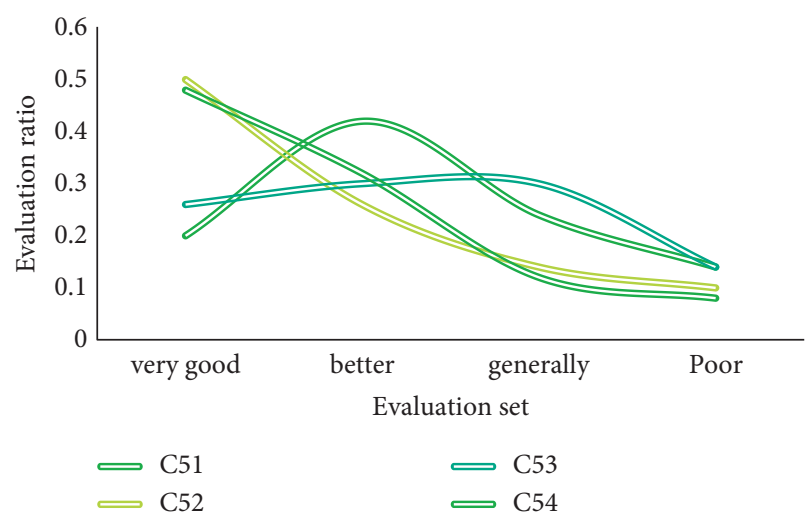

Figure 11: Proportion of government B5 evaluation.

\section{Conclusions}

This article provides a three-tier school-business collaboration organization system to provide school-business collaboration organization guarantees to ensure the effective implementation of school-business collaboration; four school-business collaboration operating mechanisms provide school-business collaboration system guarantees to ensure efficient school-business collaboration. Operation: Three school-business collaboration groups are formed to provide school-business collaboration in running schools and to integrate high-quality resources for school-business collaboration. It established a hierarchical structure model with five dimensions of teacher improvement, student training, student employment, enterprise, and government as the criterion layer and selected 21 indicators covering the above five dimensions as the program layer and used the analytic hierarchy process to pass on the school. Experts from the three aspects of enterprise and government have calculated the weights of each indicator of the model. The weights are ranked from high to low for student training, student employment, teacher promotion, enterprise, and government.

The largest collection of transaction costs, such as manpower, financial resources, resources, and technology, is the common benefit of collaborative education for all parties involved in the collaboration. Only by actively undertaking their due obligations in collaborative education, actively fulfilling their responsibilities for educating people in various roles, and working closely together and committing to the cultivation of students can the coordinated development of the regional industrial economy, and ultimately the mutual benefit of multiple parties, be realized. The government should exercise its macrocontrol and supervision functions, provide policy support and social guidance for school-business collaboration, and create a system for third-party industry association evaluation. Mechanisms ensure coordinated efforts, with each party fulfilling its responsibilities, as well as multiparty interaction, in order to cultivate high-quality, compound, and practical talents that truly serve the development of regional industrial economies, as well as to achieve sound and rapid vocational education development. Only by resolving the incentive mechanism of school-business collaboration, that is, by paying attention to the short- and long-term interests of enterprises in the process of vocational education, can we attract enterprises to participate in schoolbusiness collaboration and form a stable school-business collaboration mechanism, establishing a long-term partnership between schools and businesses.

This article examines the positive effects of schoolbusiness collaboration in today's society by looking at the history of the collaboration and the mode of cooperation. Research is even more important. The government's role in school-business collaboration is frequently overlooked in current research. This article begins with a systematic assessment of the impact of school-business collaboration projects from the three perspectives of universities, businesses, and government and ends with an empirical analysis of the experience and shortcomings of school-business collaboration in order to provide school-business collaboration.

\section{Data Availability}

The data used to support the findings of this study are included within the article. 


\section{Conflicts of Interest}

The authors declare that there are no conflicts of interest.

\section{Acknowledgments}

The study was supported by "Research on Education Mechanism of Industrial College in Higher Vocational Colleges from the Perspective of Industry-Education Integration of the 14th Five-Year Plan for Scientific Research Project of the Jiangsu Society of Higher Education China (Grant no. ZDDY21)" and "Research on Approaches to Improve the Internal Governance Efficiency of Higher Vocational Colleges of Philosophy and Social Science Research Project in Jiangsu Universities, China (Grant no. 2021SJA0951).”

\section{References}

[1] F. Shanshan, "Research on optimization of School-business collaboration system mechanism in higher vocational colleges," Journal of Liaoning Higher Vocational College, vol. 019, no. 6, pp. 13-15, 2017.

[2] C. Zhang, D. Chu, X. Xu, Z. Chen, and W. Lv, “Training plan for software engineering top talents based on the demand for high-end talents in the industry," Computer Education, vol. 288 , no. 12 , p. 7, 2018.

[3] J. Huang, "A Comparative study of school-business collaboration and work-study combination system construction in vocational education at home and abroad," Management Science and Research: Chinese and English Edition, vol. 8, no. 1, p. 4, 2019.

[4] J. Ge, X. Wu, and Y. Xu, Research on School-Business Collaboration Service Platform Based on Information Resource Sharing, China Adult Education, pp. 36-38, 2021.

[5] W. Zhang and Y. Zeng, "The construction and practice of a shared professional teaching resource library for secondary vocational education-based on School-business collaboration electrical automation equipment installation and maintenance major," Modern Vocational Education, vol. 000, no. 5, pp. 200-201, 2017.

[6] Y. Xu and J. Wang, "Research on the construction mode and practice of online open courses in vocational colleges from the perspective of school-enterprise dominance," Education Modernization, vol. 7, no. 11, pp. 88-91, 2020.

[7] Y. Liu, Discussion on School-Business Collaboration and Document Information Resource Sharing, Journal of Jixi Univerisity, pp. 145-146, 2021.

[8] W. Shi and Q. Wang, "Promoting school-enterprise normative cooperation and comprehensively advancing the integration of production and education--interpretation of "promotion measures for vocational schools and schoolsenterprise cooperation"," China Vocational and Technical Education, vol. 4, no. 10, 2018.

[9] W. Shi and Q. Wang, "Promote school-enterprise normative cooperation and comprehensively promote the integration of production and education--interpretation of the "promotion measures for vocational schools and schools-enterprise cooperation," vol. 2, pp. 15-18, 2021.

[10] Y. Tang, Exploration and Practice of School-Business Collaboration Model in Higher Vocational Colleges, China Electric Power Education, pp. 72-73, 2021.
[11] Q. Jia, Research on the Construction Of High-Quality Resource Sharing Curriculum Resources under the School-Business Collaboration Mode--Taking "Automobile Engine Mechanical System Maintenance" as an Example, Science \& Technology Information, pp. 147-148, 2021.

[12] M. Ye, A Preliminary Study on the Innovative Construction of the Management Information Platform for School-Business Collaboration In Higher Vocational Colleges, Journal of Taizhou Polytechnic College, pp. 10-12, 2021.

[13] S. Shen and S. Jiang, "The construction strategy of the teaching resource database of higher vocational colleges with Schoolbusiness collaboration-Taking the construction of higher vocational health school teaching resource database as an example," Computer Knowledge and Technology, vol. 3, no. 12X, 2016.

[14] Y. Liu, "Exploration of the operating mechanism of the "dual main body" of School-business collaboration mode of cocultivating local technical and technical talents-taking Kunshan No. 1 Secondary Vocational School in Jiangsu Province as an example," Vocational Education Newsletter, vol. 5, no. 35, 2017.

[15] L. Sun, "Research on the ways of sharing teaching resources for production, teaching, research and utilization cooperation in higher vocational colleges-taking the landscape engineering technology major of guangdong vocational college of science and trade as an example," China Forestry Education, vol. 35, no. 4, p. 5, 2017.

[16] X. Cheng, M. Zhang, and C. Huang, Research on the Architecture Technology of School-Business Collaboration Platform, Logistics Sci-Tech, pp. 53-55, 2021.

[17] N. Li and X. Cai, The Construction of High-Quality Resource Sharing Courses in Higher Vocational Colleges Under SchoolBusiness Collaboration, China Adult Education, pp. 124-126, 2021.

[18] Z. Li, Y. Zhu, and G. Chen, A Preliminary Study on the Integration of School-Business Collaboration in the Sub-Section of the Special School, Journal of Taiyuan Urban Vocational College, pp. 82-84, 2021.

[19] J. Li, M. Qiuju, and L. Shao, "Thoughts on the establishment of a "teaching resource sharing"," School-business collaboration mechanism in higher vocational education, vol. 4, pp. 58-60, 2021.

[20] S. Wu, Investigation Analysis and Countermeasure Research Based on the Service Needs of School-Enterprise Cooperative Enterprises, Journal of Academic Library and Information Science, pp. 99-102, 2021.

[21] Y. Zhao and L. Ma, Research on the Sharing of Training Resources in Higher Vocational Colleges, Journal of Luohe Vocational Technology College, pp. 153-154, 2021.

[22] Q. Qian and W. Gong, Research on Enterprise Participation in Higher Vocational Education Governance, Education and Vocation, 2021.

[23] B. Boyle, S. Nicholas, and R. Mitchell, "The value of international assignees' knowledge of interpersonal networks: knowledge of people, networks and politics and knowledge flows in multinational enterprises," Management International Review, vol. 56, no. 3, pp. 425-454, 2016.

[24] R. Spekman and E. W. Davis, "The extended enterprise: a decade later," International Journal of Physical Distribution \& Logistics Management, vol. 46, no. 1, pp. 43-61, 2016. 